Diunggah : Mei 2020

Diterima : Oktober 2020

Dipublikasi : November 2020

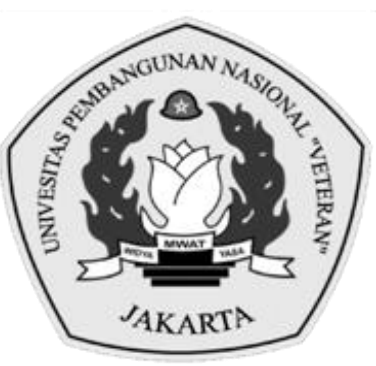

\title{
PENGALAMAN MEMODERASI PENILAIAN RISIKO KECURANGAN, SKEPTISISME, DAN INDEPENDENSI TERHADAP PENDETEKSIAN KECURANGAN
}

\author{
Veren Putri Herfransis ${ }^{1}$, Puspita Rani ${ }^{2 *}$ \\ ${ }^{1}$ verenputriaksel8@gmail.com, ${ }^{2}$ puspita.rani@gmail.com \\ 1,2Universitas Budi Luhur, Indonesia \\ *Penulis Korespondensi
}

\begin{abstract}
Abstrak
Penelitian ini bertujuan untuk menganalisis pengaruh penilaian risiko kecurangan, skeptisisme dan independensi terhadap kemampuan pendeteksian kecurangan auditor. Selain itu, penelitian ini juga menguji pengaruh antara penilaian risiko kecurangan dan pendeteksian kecurangan berdasarkan pengalaman auditor. Sampel penelitian ini adalah 77 auditor yang bekerja di 12 Kantor Akuntan Publik yang berada di wilayah Jakarta Selatan pada tahun 2019. Teknik analisis yang digunakan adalah moderated regression analysis. Hasil penelitian menunjukkan bahwa penilaian risiko kecurangan dan skeptisisme berpengaruh positif terhadap kemampuan pendeteksian kecurangan sedangkan independensi tidak berpengaruh secara signifikan. Pengalaman juga tidak memiliki pengaruh moderasi yang signifikan terhadap hubungan antara penilaian risiko kecurangan dan pendeteksian kecurangan. Hasil penelitian berimplikasi bagi para auditor independen untuk lebih berkomitmen dalam melaksanakan dan meningkatkan aktivitas penilaian risiko kecurangan serta selalu menjaga sikap skeptisisme dalam menjalankan kegiatan audit agar pendeteksian kecurangan klien semakin efektif.
\end{abstract}

Kata Kunci: Pendeteksian Kecurangan; Penilaian Risiko Kecurangan; Skeptisisme; Independensi dan Pengalaman.

\begin{abstract}
This study aims to analyze the effect of fraud risk assessment, skepticism and independence on the auditor's fraud detection ability. In addition, this study also examines the effect between fraud risk assessment and fraud detection based on auditor experience. The sample of this study is 78 auditors working in 12 public accounting firms located in South Jakarta. The analysis technique used is moderated regression analysis. The results showed that fraud risk assessment and skepticism have a significant positive effect on the ability to detect fraud while independency has no significant effect. Other results also show that experience is not able to moderate the effect of fraud risk assessment on fraud detection.
\end{abstract}

Keywords: Fraud Detection; Fraud Risk Assessment; Skepticism; Independence and Experience.

\section{PENDAHULUAN}

Perkembangan bisnis, kemajuan teknologi dan terbukanya peluang usaha yang semakin pesat di era globalisasi ini membawa manfaat yang sangat banyak

Mengutip ini sebagai: Herfransis, V. Putri \& Rani, P. 2020. Pengalaman Memoderasi Penilaian Risiko Kecurangan, Skeptisisme, dan Independensi Terhadap Pendeteksian Kecurangan. Equity, 23(1), 1-18. doi.org/10.34209/equ.v23i1.1765 
bagi masyarakat dan telah menghasilkan berbagai keuntungan, baik keuntungan material (berupa uang atau aset) maupun non-material (berupa kehidupan yang lebih baik dan jaminan sosial). Namun di sisi lain, situasi tersebut telah mengakibatkan semakin ketatnya persaingan dalam bisnis dan usaha sehingga perusahaan berusaha mencari keuntungan setinggi-tingginya, menekan biaya sekecil-kecilnya, dan menghindari kerugian. Persaingan dan tuntutan yang semakin tinggi menimbulkan banyaknya tekanan-tekanan yang harus dihadapi oleh para pelaku bisnis sehingga situasi ini dapat mengubah perilaku bisnis ke arah persaingan yang tidak sehat. Keadaan ini memaksa para pelaku usaha menjalankan kegiatannya dengan cara yang tidak jujur atau melawan hukum, salah satu contohnya adalah dengan melakukan tindak kecurangan (Sastiana, 2016).

Kecurangan atau dalam bahasa pengauditan lebih dikenal sebagai fraud dapat terjadi pada organisasi sektor publik maupun sektor swasta, baik di tingkat top management maupun di tingkat lower management (Yuara et al., 2018). Menurut Association of Certified Fraud Examiners (ACFE, 2017), fraud adalah perbuatan-perbuatan yang melawan hukum yang dilakukan dengan sengaja untuk tujuan tertentu (manipulasi atau memberikan laporan keliru terhadap pihak lain) dilakukan orang-orang dari dalam atau luar organisasi untuk mendapatkan keuntungan pribadi ataupun kelompok yang secara langsung atau tidak langsung merugikan pihak lain. Terjadinya kecurangan yang tidak dapat terdeteksi oleh pengauditan dapat memberikan efek yang merugikan bagi pengguna laporan keuangan. Berdasarkan laporan ACFE dalam Report to the Nations (2018), pada tahun 2018 rata-rata kerugian yang diakibatkan oleh kecurangan di Asia-Pasifik adalah sebesar USD 236.000 dan bertahan rata-rata 18 bulan sebelum terdeteksi. Dari kasus-kasus kecurangan tersebut, jenis kecurangan yang banyak terjadi adalah penyimpangan atas aset (asset misappropriation) (80\%), kemudian disusul dengan korupsi (51\%), dan jumlah paling sedikit (13\%) adalah kecurangan laporan keuangan (fraudulent statement). Namun walaupun demikian kecurangan laporan keuangan berdampak pada kerugian paling besar yaitu rata-rata kerugian sebesar \$ 700 juta.

Kecurangan laporan keuangan sering dilakukan oleh perusahaan yang mengalami krisis finansial dan dimotivasi oleh oportunisme yang salah arah (misguided opportunism) (Suryadi et al., 2017). Salah satu kasus mengenai kecurangan laporan keuangan yang terjadi di Indonesia baru-baru ini, ialah kasus PT Garuda Indonesia (Persero) Tbk pada tahun 2019. Menurut informasi yang dihimpun dari CNBC Indonesia, kejanggalan pada laporan keuangan Garuda bermula dari laporan keuangan perusahaan yang membukukan laba bersih US\$ 809.846 pada 2018 atau setara Rp 1,49 miliar (Kurs Rp 14.200/US\$). Padahal, apabila melihat lebih detail dan komprehensif, Garuda seharusnya merugi.

Pencegahan dan pendeteksian kecurangan menjadi hal yang sangat penting untuk mengurangi kerugian yang dapat ditimbulkan oleh tindakan fraud manajemen (Kiswanto dan Maulana, 2019). Pendeteksian kecurangan seharusnya dapat dilakukan oleh auditor sebagai pihak independen yang bertugas menilai kewajaran laporan keuangan yang disajikan perushaan. Anggriawan (2014) dalam Kiswanto dan Maulana (2019) berpendapat bahwa kemampuan dalam mendeteksi kecurangan adalah sebuah kecakapan atau keahlian yang dimiliki oleh auditor untuk menemukan gejala kemungkinan adanya kecurangan. Oleh karena itu, 
auditor harus memiliki keyakinan memadai bahwa salah saji material tidak terdapat dalam laporan keuangan yang sebabkan oleh kesalahan maupun kecurangan, sebagai dasar pemberian opini audit.

Penelitian terdahulu telah membuktikan bahwa kemampuan pendeteksian kecurangan seorang auditor dipengaruhi oleh banyak faktor. Faktor pertama yang mempengaruhi pendeteksian kecurangan salah satunya adalah penilaian risiko kecurangan. Auditor harus mampu mengidentifikasi dan menilai risiko kecurangan pada laporan keuangan untuk melaksanakan prosedur audit lanjutan. Walaupun kecurangan biasanya disembunyikan, namun adanya faktor penilaian risiko kecurangan dapat memperingatkan auditor tentang kemungkinan adanya kecurangan (Standar Audit 316). Penelitian yang dilakukan oleh Kiswanto dan Maulana (2019) serta Aminudin dan Suryandari (2016) telah membuktikan bahwa penilaian risiko kecurangan berpengaruh positif dan signifikan terhadap kemampuan auditor dalam mendeteksi kecurangan. Hasil penelitian berbeda diperoleh oleh Jaffar et al. (2011) yang menunjukkan bahwa keammpuan auditor eksternal untuk menilai risiko kecurangan tidak memiliki pngaruh signifikan terhadap kemampuan auditor dalam mendeteksi kecurangan.

Faktor lain yang diduga mempengaruhi tingkat pendeteksian kecurangan adalah skeptisisme. Skeptisisme profesional mengacu pada sikap sinisme yang konsisten dan kebiasaan menunda penilaian sampai seorang individu memperoleh informasi atau bukti yang cukup (Hurtt, 2010). Skeptisisme profesional membantu seorang auditor dalam mengumpulkan informasi yang kuat sebagai dasar bukti audit untuk mendukung pemberian opini atas kewajaran suatu laporan keuangan. Sikap skeptisisme yang semakin tinggi akan meningkatkan kemampuan auditor dalam pendeteksian kecurangan (Kiswanto dan Maulana, 2019; Indrawati et al., 2019; Yuara et al., 2018; Sari et al., 2018 serta Sofie dan Nugroho, 2018). Namun di sisi lain Ningtyas et al. (2018) menyimpulkan dalam penelitiannya bahwa sikap skeptisisme tidak memiliki pengaruh signifikan terhadap pendeteksian kecurangan pada auditor di BPK RI perwakilan Sumatera Selatan.

Hal lain yang harus dimiliki auditor dalam menjalankan tugasnya adalah independensi. Independen berarti seorang akuntan publik tidak mudah dipengaruhi oleh orang lain ataupun kondisi, dan bersikap jujur tidak hanya kepada manajemen atau pemilik perusahaan namun juga kepada semua pihak berkepentingan yang memberikan kepercayaan pada auditor (Sulistyowati dan Supriyati, 2015). Saat melakukan proses audit, auditor harus mampu mempertahankan sikap independensi agar tidak memihak kepada siapapun dan dapat bersikap objektif, terlebih bila ditemukan tindak kecurangan pada laporan keuangan (Sofie dan Nugroho, 2018). Sofie dan Nugroho (2018) dan Indrawati et al. (2019) serta Biksa dan Wiratmaja (2016) telah membuktikan bahwa independensi auditor berpengaruh positif terhadap kemampuan auditor mendeteksi kecurangan, yaitu ketika auditor semakin menjaga independensinya maka akan meningkatkan kemampuan pendeteksian kecurangan saat menjalankan pekerjaan audit. Namun hasil tersebut bertentangan dengan Prasetyo et al. (2019) dan Sulistyowati dan Supriyati (2015) yang membuktikan bahwa independensi auditor tidak berpengaruh secara signifikan terhadap kemampuan pendeteksian kecurangan.

Selain faktor-faktor yang mempengaruhi pendeteksian kecurangan secara 
langsung, mengacu pada Kiswanto dan Maulana (2019), penelitian ini juga menduga bahwa terdapat efek moderasi yang dapat ditimbulkan oleh pengalaman auditor terhadap hubungan antara penilaian risiko kecurangan dengan pendeteksian kecurangan. Pengalaman memiliki peran dalam hal mendeteksi kecurangan klien. Auditor yang berpengalaman lebih banyak tentunya memiliki pengetahuan dan kompetensi yang lebih baik sehingga dapat berpikir lebih kritis terhadap bukti audit yang diperoleh dan serta memecahkan permasalahan yang dihadapi saat menjalankan tugas audit (Putra dan Dwiranda, 2019). Terkait dengan penilaian risiko kecurangan, auditor yang lebih berpengalaman akan dapat menjalankan prosedur penilaian risiko kecurangan dengan lebih efektif dibandingkan auditor yang kurang berpengalaman (Knapp \& Knap, 2001). Dengan demikian maka dapat diduga bahwa dampak kemampuan penilaian risiko kecurangan terhadap kemampuan pedeteksian kecurangan auditor dapat berbeda tergantung dari pengalaman auditor yang bertugas. Hasil penelitian terdahulu Kiswanto dan Maulana (2019) telah membuktikan bahwa pengalaman dapat memoderasi pengaruh penilaian risiko kecurangan terhadap kemampuan auditor dalam mendeteksi kecurangan.

Berdasarkan uraian tersebut maka penelitian ini dilakukan dengan tujuan untuk menguji pengaruh penilaian risiko kecurangan, sikap skepstisisme dan tingkat independensi terhadap pendeteksian kecurangan. Dengan adanya variasi hasil penelitian sebelumnya, maka penelitian ini akan menambah bukti empiris yang memperkuat hasil penelitian sebelumnya dengan menggunakan sampel auditor yang berbeda yaitu auditor pada Kantor Akuntan Publik di wilayah Jakarta Selatan. Selain itu penelitian ini juga menguji pengaruh moderasi yang dihasilkan oleh pengalaman terhadap hubungan antara penilaian risiko kecurangan dan kemampuan pendeteksian kecurangan yang relatif belum banyak diteliti oleh peneliti terdahulu. Pengaruh moderasi pengalaman diuji untuk mengetahui apakah pengaruh penilaian risiko kecurangan terhadap pendeteksian kecurangan akan berbeda pada auditor yang berpengalaman dan tidak.

Sistematika pembahasan dalam studi ini diawali dengan pemaparan latar belakang studi, dilanjutkan dengan pembahasan teori serta pengembangan hipotesis penelitian, kemudian penjelasan mengenai metode penelitian disusul pemaparan hasil penelitian beserta pembahasannya, dan terakhir merupakan kesimpulan penelitian yang menjadi penutup studi ini.

\section{TINJAUAN PUSTAKA}

\section{Teori Atribusi}

Teori ini pertama kali dikemukakan oleh Hieder (1985). Pada dasarnya, teori ini menjelaskan bahwa perilaku seorang individudapat disebabkan oleh faktor internal atau faktor eksternal. Perilaku internal adalah perilaku yang dipengaruhi oleh kendali pribadi seorang individu, seperti kemampuan dan usaha. Sedangkan perilaku yang disebabkan oleh faktor eksternal dianggap sebagai akibat dari sebab-sebab di luar kendali diri, individu tersebut telah berperilaku demikian disebabkan oleh situasi tertentu, seperti beban kerja, tekanan waktu dan lain sebagainya. 
Serupa dengan Jaffar et al. (2011), Kiswanto dan Maulana (2019) dan Aminudin dan Suryandari (2016), penelitian ini menggunakan teori atribusi sebagai dasar yang menjelaskan faktor-faktor yang mempengaruhi kemampuan pendeteksian kecurangan auditor. Teori atribusi dapat digunakan untuk menjelaskan bahwa kemampuan auditor dalam mendeteksi kecurangan dapat dipengaruhi dari faktor internal auditor seperti kemampuan melakukan penilaian risiko kecurangan, skeptisisme, independensi, dan pengalaman.

\section{Pengembangan Hipotesis Penelitian}

Pengaruh Penilaian Risiko Kecurangan terhadap Pendeteksian Kecurangan

Kemampuan auditor dalam mendeteksi kecurangan dapat dipengaruhi dari faktor internal auditor yaitu kemampuan dalam melakukan penilaian risiko kecurangan. Menurut Noviyanti (2008) dalam Kiswanto dan Maulana (2019), penilaian risiko kecurangan adalah penaksiran seberapa besar risiko kegagalan auditor dalam mendeteksi terjadinya kecurangan dalam asersi manajemen.

Adanya proses identifikasi risiko kecurangan tersebut membantu auditor untuk mendeteksi kemungkinan kecurangan organisasi yang diauditnya. Ketika auditor sensitif terhadap risiko kecurangan maka auditor akan semakin baik dalam mengidentifikasi tindak kecurangan klien audit yang dihasilkan dari penilaian risiko kecurangan yang tinggi (Capenter, 2013 dalam Aminudin dan Suryandari, 2016). Berdasarkan pada penilaian risiko kecurangan, auditor harus mampu melihat kondisi seperti apa yang dapat memicu tindak kecurangan pada perusahaan, seperti tidak adanya pemisahan tugas yang memadai, otorisasi transaksi yang tidak terkendali, dan sebagainya. Dengan melihat kondisi-kondisi tersebut, auditor akan meningkatkan perhatiannya terhadap tanda-tanda kecurangan. Selain itu kemampuan seorang auditor dalam menilai dan menggunakan atribut tertentu dalam menilai risiko kecurangan dapat meningkatkan pendeteksi kecurangan yang dilakukan oleh klien atau perusahaan, sehingga kesuksesan masa depan dalam pelaksanaan audit sangat ditentukan oleh adanya atribut yang dipakai dalam mendeteksi kecurangan yang mungkin terjadi (Kiswanto dan Maulana, 2019). Penelitian yang dilakukan Kiswanto dan Maulana (2019), serta Aminudin dan Suryandari (2016) telah membuktikan bahwa penilaian risiko kecurangan berpengaruh positif terhadap pendeteksian kecurangan. Dengan demikian maka dapat dirumuskan hipotesis sebagai berikut:

\section{H1: Penilaian risiko kecurangan berpengaruh positif terhadap pendeteksian kecurangan.}

\section{Pengaruh Skeptisisme terhadap Pendeteksian Kecurangan}

Standar Audit (SA) 200 mendefinisikan skeptisisme profesional sebagai suatu sikap yang mencakup suatu pikiran yang selalu mempertanyakan, waspada terhadap kondisi yang dapat mengindikasikan kemungkinan kesalahan penyajian, baik yang disebabkan oleh kecurangan maupun kesalahan, dan suatu penilaian penting atas bukti audit. Auditor harus merencanakan dan melaksanakan audit dengan skeptisisme profesional mengingat kondisi tertentu dapat saja terjadi yang menyebabkan laporan keuangan mengandung kesalahan penyajian material.

Carpenter dan Reimers (2013) dalam Kiswanto dan Maulana (2019) mengungkapkan bahwa jika auditor lebih skeptis, auditor akan lebih mampu 
menaksir keberadaan kecurangan pada tahap perencanaan audit yang akhirnya akan mengarahkan auditor untuk meningkatkan pendeteksian kecurangan. Skeptisisme terjadi ketika terdapat keraguan terkait reliabiltas informasi yang diterima. Ketika seorang auditor memiliki keraguan terkait reliabilitas informasi dari klien, maka auditor akan mencari indikasi-indikasi lain melalui pencarian informasi lebih melalui ataupun pengecekan tambahan untuk meyakinkan dirinya dalam membuat suatu audit judgment sehingga peluang untuk menemukan kecurangan audit lebih tinggi (Sayed Hussin et al. 2017, Putra dan Dwiranda, 2019)). Penjelasan tersebut didukung oleh hasil penelitian terdahulu yang dilakukan oleh Kiswanto dan Maulana (2019), Indrawati et al. (2019), Putra dan Dwiranda (2019) serta Yuara et al. (2018) yang membuktikan bahwa skeptisisme berpengaruh positif terhadap kemampuan mendeteksi kecurangan, yaitu ketika skeptisisme auditor semakin tinggi akan dapat mendeteksi kecurangan dengan lebih baik daripada auditor yang memiliki skeptisisme rendah. Auditor dengan skeptisisme yang lebih tinggi akan mampu mengestimasi keberadaan fraud pada tahap perencanaan audit sehingga Berdasarkan uraian tersebut, maka dapat dirumuskan hipotesis sebagai berikut:

\section{H2: Skeptisisme berpengaruh positif terhadap pendeteksian kecurangan.}

\section{Pengaruh Independensi terhadap Pendeteksian Kecurangan}

Mulyadi (2014) menyatakan bahwa independensi berarti sikap mental yang bebas dari pengaruh, tidak dikendalikan oleh pihak lain, dan tidak bergantung pada orang lain. Independensi juga berarti adanya kejujuran dalam diri auditor dalam mempertimbangkan fakta dan adanya pertimbangan objektif dan tidak memihak kepada pihak manapun. Auditor yang mampu mempertahankan sikap independensinya akan mendapat kepercayaan publik bahwa laporan keuangan yang diauditnya bebas dari salah saji material, karena auditor dipercaya menggunakan kejujurannya dalam mempertimbangkan fakta serta tidak memihak dalam pemberian opini auditnya (Sofie dan Nugroho, 2018).

Ketika memiliki independensi yang baik, auditor akan cenderung menilai kliennya secara objektif tanpa adanya tekanan dan ketergantungan dengan pihak manapun, sehingga auditor dapat menggunakan kemampuannya dalam mendeteksi kecurangan yang ada dalam perusahaan dengan lebih baik. Indrawati et al. (2019), Sofie dan Nugroho (2018) dan Biksa dan Wiratmaja (2016) telah membuktikan bahwa independensi berpengaruh secara positif dan signifikan terhadap pendeteksian kecurangan. Dengan demikian, maka dapat dirumuskan hipotesis sebagai berikut:

\section{H3: Independensi berpengaruh positif terhadap pendeteksian kecurangan.}

\section{Pengalaman Memoderasi Pengaruh Penilaian Risiko Kecurangan terhadap Pendeteksian Kecurangan}

Pengalaman adalah lamanya waktu yang dihabiskan individu untuk berkarya dan menerapkan keahliannya di masyarakat, bagi auditor pengalaman adalah kekuatan internal yang mempengaruhi perilaku auditor dalam bertindak (Sari et al., 2018). Auditor yang berpengalaman akan memiliki tingkat presisi dan akurasi yang tinggi dalam menilai laporan keuangan klien dan memberikan dampak positif bagi kualitas audit yang dihasilkan (Sari et al., 2018; Sulistyowati 
dan Supriyati, 2015). Auditor yang berpengalaman diasumsikan dapat mendeteksi adanya tindak kecurangan dengan lebih baik dibandingkan auditor yang belum berpengalaman, dikarenakan baik secara teknis dan psikis, keahlian auditor akan dibentuk dari pengalaman (Sari et al., 2018).

Dalam hal penilaian risiko kecurangan, pengalaman dapat memiliki peran yang meningkatkan efektifitas dari penilaian risiko kecurangan yang dilakukan. Keberhasilan atau kegagalan auditor dalam menggunakan penilaian risiko kecurangan salah satunya bergantung pada pengalaman. Karena auditor yang memiliki pengalaman lebih akan semakin mahir dalam menggunakan kemampuan penilaian risiko kecurangan yang dimilikinya dalam mendeteksi satu tindakan kecurangan perusahaan (Kiswanto dan Maulana, 2019). Dengan kemampuan penilaian risiko kecurangan yang baik dilengkapi dengan banyaknya pengalaman yang dimiliki maka informasi yang diperoleh saat prosedur penilaian risiko kecurangan akan dapat diinterpretasikan dengan lebih baik lagi dibandingkan pada auditor kurang berpengalaman, sehingga pada akhirnya akan lebih meningkatkan dampak positif dari aktivitas penilaian risiko kecurangan terhadap pendeteksian kecurangan. Penelitian sebelumnya yang dilakukan oleh Kiswanto dan Maulana (2019) menyatakan bahwa pengalaman dapat memperkuat secara positif pengaruh penilaian risiko kecurangan terhadap pendeteksian kecurangan. Berdasarkan penjelasan tersebut, maka dapat dirumuskan hipotesis sebagai berikut:

H4: Pengalaman memoderasi pengaruh penilaian risiko kecurangan terhadap pendeteksian kecurangan.

\section{METODOLOGI PENELITIAN}

\section{Sampel penelitian}

Populasi yang digunakan dalam penelitian ini adalah auditor yang bekerja di Kantor Akuntan Publik (KAP) yang berada di wilayah Jakarta Selatan. Kantor Akuntan Publik (KAP) wilayah Jakarta Selatan dipilih sebagai objek penelitian karena berdasarkan data dari Direktorat Institut Akuntan Publik Indonesia tahun 2019 menunjukkan bahwa wilayah Jakarta Selatan memiliki jumlah Kantor Akuntan Publik lebih banyak dibandingkan wilayah Jakarta lainnya yaitu sebanyak 106 Kantor Akuntan Publik (KAP). Pengambilan sampel yang digunakan dalam penelitian ini menggunakan teknik convenience sampling. Responden merupakan auditor yang bekerja pada KAP di wilayah Jakarta Selatan yang dapat dijangkau penelitian dan bersedia untuk mengisi kuesioner.

\section{Teknik Pengumpulan Data}

Data penelitian dikumpulkan melalui pembagian kuesioner kepada sampel penelitian atau responden. Kuesioner yang dibagikan berisi kumpulan pertanyaan yang mewakili indikator-indikator dari setiap variabel penelitian. Pembagian kuesioner dilakukan secara langsung dengan mengunjungi Kantor Akuntan Publik yang telah memberikan konfirmasi kesediaan mengisi kuesioner. Kesediaan pengisian kuesioner ditanyakan melalui telepon ataupun kunjungan langsung ke KAP sebelum kuesioner dibagikan. Pembagian kuesioner dilakukan pada bulan 
November dan Desember tahun 2019. Setiap pertanyan diukur dengan skala likert yang mewakili lima kategori jawaban dengan skor terendah sebesar 1 (satu) dan skor terbesar bernilai 5 (lima).

\section{Model Penelitian}

Penelitian ini mengadopsi model yang digunakan oleh Kiswanto dan Maulana (2019) dengan perubahan komposisi variabel bebas yang digunakan, maka model penelitian yang diuji dalam penelitian ini adalah sebagai berikut:

$$
P K_{i}=\beta O_{i}+\beta_{1} R I S K_{i}+\beta_{2} S K E P_{i}+\beta_{3} I N D_{i}+\beta_{4} E X P_{i}+\beta_{5} R I S K_{i}^{*} E X P_{i}+e
$$

Keterangan:

$P K \quad$ : Pendeteksian Kecurangan

RISK : Penilaian Risiko Kecurangan

SKEP : Skeptisisme

IND : Independensi

EXP : Pengalaman

Jenis data bersifat cross-section yaitu data diperoleh pada satu waktu dengan beberapa sampel pengamatan yang berbeda. Analisis data yang digunakan dalam penelitian ini yaitu moderated regression analysis. Hipotesis 1 dibuktikan melalui nilai $\beta_{1}$ dengan prediksi nilai positif, $\beta_{2}$ mewakili pengujian hipotesis 2 mengenai pengaruh skeptisisme terhadap pendeteksian kecurangan. Hipotesis 3 dibuktikan melalui nilai $\beta_{3}$ dan hipotesis 4 dibuktikan melalui $\beta_{5}$ yang merupakan interaksi dari variabel penilaian risiko kecurangan dan pengalaman. Data penelitian merupakan data bersifat cross-section sehingga pengujian asumsi klasik dilakukan dengan meliputi uji normalitas, uji multikolinearitas dan uji heteroskedastisitas. Pengujian normalitas dilakukan dengan menggunakan uji kolmogorov-smirnov, uji multikolinearitas dinilai berdasarkan nilai Variance Inflation Factor (VIF) dan uji heteroskedastisitas dilakukan dengan menggunakan uji glejser. Sebelum pengujian model dilakukan, dilakukan terlebih dahulu pengujian validitas dan reliabilitas untuk semua item pertanyaan dalam kuesioner.

\section{Operasionalisasi Variabel}

Pengumpulan data dalam penelitian ini dilakukan melalui pembagian kuesioner kepada auditor secara langsung. Setiap variabel diukur melalui jawaban responden atas setiap indikator dari variabel yang bersangkutan. Pengukuran variabel pendeteksian kecurangan (PK) dalam penelitian ini mengacu pada Irawan et al. (2018) dan Koroy (2008) yang menggunakan indikator sebagai berikut: 1) Pemahaman auditor akan sistem pengendalian internal, 2) pemahaman auditor mengenai karakteristik kecurangan meliputi kemampuan identifikasi indikatorindikator kecurangan, memahami karakteristik terjadinya kecurangan eksistensi standar audit yang digunakan untuk mendeteksi kcurangan, 3) lingkungan audit yang mendukung pelaksanaan audit, 4) metode audit yang digunakan meliputi efektifitas metode dan prosedur audit yang digunakan serta adanya susunan langkah-langkah pendeteksian kecurangan, 5) bentuk kecurangan yang meliputi kemampuan auditor untuk menemukan faktor-faktor penyebab kecurangan, 
perkiraan bentuk kecurangan yang bisa terjadi serta mampu mengidentifikasi pihak yang berpotensi melakukan kecurangan, dan 6) uji dokumentasi dan personal yang meliputi pengujian dokumen atau informasi yang diperoleh serta kondisi mental dan pengawasan kerja. Total pertanyaan dalam variabel pendeteksian kecurangan adalah sebanyak 12 pertanyaan.

Selanjutnya untuk variabel penilaian risiko kecurangan (RISK) diukur dengan menggunakan lima indikator yang diadopsi dari Kiswanto dan Maulana (2019) yang meliputi: 1) Pemisahan tugas yang tepat, 2) Otorisasi transaksi dan aktivitas perusahaan, 3) Dokumentasi dan pencatatan yang memadai, 4) Pengendalian fisik atas aset dan dokumen perushaan serta 5) Ketersediaan penilaian independen atas kinerja. Kelima indikator tersebut mewakili kondisi yang mencerminkan risiko kecurangan pada perusahaan. Skor jawaban memiliki nilai terendah 1 dan nilai terbesar 5. Semakin besar skor jawaban menunjukkan semakin intensif aktivitas penilaian risiko yang dilakukan auditor pada saat menyelesaikan tugas audit.

Pengukuran untuk variabel skeptisisme (SKEP) diwakili oleh 13 indikator pertanyaan mengacu pada Butar dan Perdana (2017) yaitu mencakup: 1) Pikiran yang selalu mempertanyakan sesuatu yang diwakili dengan sikap menolak suatu pernyataan tanpa pembuktian yang jelas dan selalu mengajukan banyak pertanyaan untuk pembuktian suatu hal, 2) penangguhan dalam penilaian yang dilakukan karena membutuhkan informasi yang lebih banyak, membutuhkan waktu dalam membuat suatu keputusan serta sikap tidak akan membuat keputusan jika semua informasi belum terungkap, 3) pencarian pengetahuan yang diwakili dengan sikap banyak mencari dan berusaha menemukan informasi baru yang up to date serta merasa senang bila menemukan hal-hal yang baru, 4) berusaha memahami perilaku orang lain, 5) Percaya akan kapasitas dan kapabilitas diri sendiri, serta 6) determinasi diri yang meliputi sikap tidak langsung menerima atau membenearkan pernyataan dari orang lain, mempertimbangkan penjelasan dan tanggapan orang lain, menekankan pada suatu hal yang bersifat tidak konsisten dan tidak mudah dipengaruhi oleh orang lain terkait suatu hal.

Variabel selanjutnya yaitu independensi (IND) diukur melalui 4 indikator yang yaitu auditor dapat dilihat dari beberapa hal berikut: 1) lama hubungan auditor dan klien, 2) tekanan dari klien, 3) telaah dari rekan auditor lain, 4) pemberian jasa non audit kepada klien (Dewi dan Budhiarta, 2015). Dan variabel terakhir yaitu pengalaman (EXP) yang diwakili oleh 4 indikator berikut: 1) lamanya pengalaman sebagai auditor, 2) banyaknya penugasan audit yang diselesaikan, 3) banyaknya pelatihan yang pernah diikuti dan 4) jabatan auditor.

\section{HASIL DAN PEMBAHASAN}

\section{Gambaran Responden}

Dari proses pengumpulan data, diperoleh 77 kuesioner yang telah terisi lengkap dan dikembalikan oleh responden. Berdasarkan Tabel 1 menunjukkan bahwa dari hasil penyebaran kuesioner sebanyak 77 orang responden, pada karakteristik jenis kelamin terdapat 42 responden (55\%) yang berjenis kelamin 
laki-laki dan 35 responden (45\%) berjenis kelamin perempuan. Kemudian pada karakteristik usia terdapat 62 responden (80\%) yang berusia $<30$ tahun, 13 responden (17\%) berusia 31-35 tahun, dan 2 responden (3\%) berusia $>40$ tahun. Karakteristik pendidikan terakhir responden menunjukkan terdapat 71 responden (92\%) adalah lulusan S1 (Strata Satu) dan 6 responden (8\%) lulusan S2 (Strata Dua). Dari karakteristik lama masa kerja terlihat bahwa mayoritas responden (51 orang atau 66\%) telah bekerja sebagai auditor selama 1-5 tahun dan hanya 11 responden yang memiliki masa kerja $>5$ tahun. Karakteristik sampel juga menunjukkan bahwa mayoritas responden dalam penelitian ini adalah auditor yang saat ini menempati posisi sebagai auditor junior yaitu sebanyak 42 orang (55\%) dari total 77 responden yang disusul oleh auditor senior sebanyak 30 orang $(39 \%)$.

Tabel 1

Gambaran Umum Karakteristik Responden

\begin{tabular}{llcc}
\hline Karakteristik & Keterangan & Jumlah & Persentase \\
\hline Jenis Kelamin & Laki-Laki & 42 & $55 \%$ \\
& Perempuan & 35 & $45 \%$ \\
\cline { 2 - 4 } & Jumlah & 77 & $100 \%$ \\
\hline Usia & $<30$ tahun & 62 & $80 \%$ \\
& $31-35$ tahun & 13 & $17 \%$ \\
& $>40$ tahun & 2 & $3 \%$ \\
\cline { 2 - 4 } Pendidikan & Jumlah & 77 & $100 \%$ \\
Serakhir & S2 (Strata Satu) & 71 & $92 \%$ \\
& Jumlah & 6 & $8 \%$ \\
\hline Masa Kerja & $<1$ tahun & 17 & $100 \%$ \\
& $1-5$ tahun & 51 & $20 \%$ \\
& $6-10$ tahun & 9 & $66 \%$ \\
& $10-15$ tahun & 1 & $12 \%$ \\
& $>15$ tahun & 1 & $1 \%$ \\
\cline { 2 - 4 } & Jumlah & 77 & $100 \%$ \\
\hline Jabatan auditor & Auditor Junior & 42 & $55 \%$ \\
& Auditor Senior & 30 & $39 \%$ \\
& Supervisor & 4 & $5 \%$ \\
& Manajer & 1 & $1 \%$ \\
& Partner & 0 & $0 \%$ \\
\cline { 2 - 4 } & Jumlah & 77 & $100 \%$ \\
\hline
\end{tabular}

Sumber : Data yang telah diolah, 2020

\section{Uji Validitas dan Reliabilitas}

Uji validitas dilakukan terhadap seluruh item pertanyaan pada kuesioner dengan membandingkan nilai $r_{\text {hitung }}$ dan $r_{\text {tabel, }}$ sedangkan untuk uji reliabilitas menggunakan nilai Cronbach's Alpha. Ringkasan output nilai corrected item totalcorrelation dan cronbach's alpha yang dihasilkan tersaji pada Tabel 2. 
Tabel 2

Ringkasan Nilai Corrected Item - Total Correlation dan Cronbach Alpha

\begin{tabular}{cccccc}
\hline No Pertanyaan & PK & FRA & SKEP & IND & EXP \\
\hline 1 & 0,490 & 0,278 & 0,625 & 0,541 & 0,665 \\
\hline 2 & 0,652 & 0,453 & 0,546 & 0,443 & 0,660 \\
\hline 3 & 0,562 & 0,429 & 0,498 & 0,433 & 0,680 \\
\hline 4 & 0,467 & 0,519 & 0,499 & 0,488 & 0,588 \\
\hline 5 & 0,434 & 0,445 & 0,440 & & \\
\hline 6 & 0,438 & & 0,425 & & \\
\hline 7 & 0,619 & & 0,429 & & \\
\hline 8 & 0,602 & & 0,500 & & \\
\hline 9 & 0,532 & & 0,601 & & \\
\hline 10 & 0,440 & & 0,446 & & \\
\hline 11 & 0,432 & & 0,467 & & \\
\hline 12 & 0,477 & & 0,604 & & \\
\hline 13 & 0,839 & 0,659 & 0,841 & 0,689 & 0,793 \\
\hline Cronbach's Alpha & &
\end{tabular}

Sumber: data diolah

Dari Tabel 2 tersebut terlihat bahwa semua indikator pertanyaan dari setiap variabel penelitian memiliki nilai r-hitung (corrected item-total correlation) yang lebih besar dari $r_{\text {tabel }}(0,2242)$ sehingga dapat disimpulkan bahwa semua butir pertanyaan telah valid. Di samping itu, Tabel 2 juga menunjukkan bahwa nilai Cronbach's Alpha semua variabel penelitian lebih besar dari 0,60 sehingga dapat disimpulkan bahwa variabel penelitian reliabel.

\section{Uji Asumsi Klasik}

Hasil dari uji grafik normal p-plot menunjukkan bahwa data residual berdistribusi normal karena titik-titik data menyebar disekitar garis diagonal dan mengikuti arah garis diagonal. Dan hasil dari uji kolmogorov-smirnov test juga menyatakan bahwa data berdistribusi normal karena nilai signifikansi Asymp. Sig. (2-tailed) bernilai $0,656(0,656>0,05)$. Hasil uji multikolinearitas pada penelitian ini menunjukkan bahwa tidak terdapat multikolinearitas karena nilai VIF masingmasing variabel independen kurang dari 10 dan nilai tolerance masing-masing variabel independen lebih dari 0,1. Dan hasil uji glejser menyatakan bahwa model regresi tidak terdapat gejala heterokedastisitas karena nilai signifikansi untuk masing-masing variabel independen lebih besar dari 0,05. Sehingga dapat disimpulkan bahwa model penelitian telah memenuhi asumsi klasik.

\section{Analisis Regresi}

Berikut ini merupakan rangkuman hasil analisis regresi yang dilakukan terhadap data penelitian: 
Tabel 7

Output Koefisien Regresi

Model Penelitian:

\begin{tabular}{l|c|r|r|r}
\multicolumn{5}{c}{$P K_{i}=\alpha_{i}+\beta_{1} F R A_{i}+\beta_{2} S K E P_{i}+\beta_{3} I N D_{i}+\beta_{4} E X P_{i}+\beta_{5} F R A_{i}{ }^{*} E X P_{i}+e$} \\
\hline \multicolumn{1}{c|}{ Variabel dependen = Pendeteksian Kecurangan (PK) } \\
\hline FRA & Prediksi & Koefisien & t-hitung & signifikansi \\
\hline SKEP & + & .690 & 2.412 & $0,018^{* *}$ \\
\hline IND & + & .427 & 3.187 & $0,002^{* * *}$ \\
\hline EXP & + & .167 & .757 & 0,452 \\
\hline FRAEXP & + & .300 & 1.719 & $0,090^{*}$ \\
\hline (Constant) & +- & 20,010 & 3,918 & $0,000^{* * *}$ \\
\hline N (observasi) & \multicolumn{5}{|c}{77} \\
\hline Adjusted R-Square & \multicolumn{5}{c}{$57,8 \%$} \\
\hline F-hitung (sig) & \multicolumn{5}{c}{$21,851(0,000)$} \\
\hline Keterangan:
\end{tabular}

Keterangan:

$*, * *, * * *$ Signifikan pada tingkat $10 \%, 5 \%$ dan $1 \%$ (secara berurutan)

PK: Pendeteksian kecurangan, FRA; Penilaian risiko kecurangan, SKEP:

Skeptisme, IND: Independensi auditor, EXP: Experience

Sumber : Output pengolahan data

Tabel 7 menunjukkan beberapa informasi mengenai hasil pengujian regresi yang dilakukan terhadap 77 data responden. Pertama, nilai koefisien determinan yang diwakili oleh angka adjusted R-Square bernilai 57,8\% yang menunjukkan bahwa secara simultan pengaruh penilaian risiko kecurangan, skeptisisme dan independensi terhadap pendeteksian kecurangan dimoderasi oleh pengalaman adalah sebesar 57,8\%, sedangkan sisanya sebesar 42,2\% dipengaruhi oleh variabel lain di luar model penelitian. Kedua, Tabel 7 menunjukkan bahwa model regresi

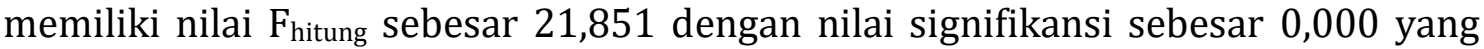
model regresi yang dianalisis layak untuk digunakan.

Ketiga, Tabel 7 menunjukkan output mengenai koefisien regresi untuk tiap variabel yang merupakan dasar pengambilan kesimpulan dalam penelitian ini. Diketahui bahwa koefisien variabel penilaian risiko kecurangan (FRA) bernilai positif $(0,690)$ dengan tingkat signifikansi sebesar 0,018 yang lebih kecil dari 0,05 sehingga menunjukkan bahwa $\mathrm{H}_{1}$ dapat diterima. Hasil tersebut menunjukkan bahwa penilaian risiko kecurangan yang dilakukan auditor secara signifikan mempengaruhi kemampuan pendeteksian kecurangan saat auditor melakukan tugas audit dengan arah positif. Hasil tersebut konsisten dengan penelitian Kiswanto dan Maulana (2019) serta Aminudin dan Suryandari (2016) yang menunjukkan bahwa penilaian risiko kecurangan berpengaruh positif signifikan terhadap kemampuan auditor dalam mendeteksi kecurangan. Penilaian risiko kecurangan yang dilakukan oleh auditor dalam pekerjaan auditnya merupakan faktor penting dalam kemampuan pendeteksian kecurangan auditor dikarenakan dengan menilai tingkat risiko kecurangan klien maka auditor dapat mendeteksi lebih awal gejala-gejala kecurangan yang mungkin dilakukan perusahaan sehingga memudahkan auditor untuk lebih dapat mendeteksi kecurangan perusahaan. 
Temuan ini mendukung teori atribusi yang menyatakan bahwa perilaku atau kinerja individu (dalam hal ini kemampuan mendeteksi kecurangan) dipengaruhi oleh faktor internal dari individu tersebut yaitu salah satunya adalah kemampuan auditor dalam penilaian risiko kecurangan.

Berikutnya, hasil analisis pada Tabel 7 menunjukkan bahwa variabel skeptisisme (SKEP) berpengaruh positif terhadap pendeteksian kecurangan (H2 signifikan terbukti). Berdasarkan hasil tersebut dapat dijelaskan bahwa semakin tinggi sikap skeptisisme yang dimiliki auditor, maka semakin tinggi pula kemampuan pendeteksian kecurangan yang dimilikinya sehingga kemungkinan terjadinya kecurangan juga semakin kecil dan sebaliknya jika seorang auditor memiliki sikap skeptisisme yang rendah maka akan mengurangi kemampuannya mendeteksi kecurangan. Penelitian ini mendukung hasil penelitian Kiswanto dan Maulana (2019), Putra dan Dwiranda (2019), Sofie dan Nugroho (2018), Yuara et al. (2018), Sari et al. (2018), Indrawati et al. (2019) serta Biksa dan Wiratmaja (2016) yang menunjukkan bahwa skeptisisme berpengaruh positif terhadap pendeteksian kecurangan. Namun hasil tersebut tidak konsisten dengan Ningtyas et al. (2018) yang menyimpulkan tidak berpengaruhnya sikap skeptisisme terhadap pendeteksian kecurangan. Skeptisisme berpengaruh signifikan terhadap pendeteksian kecurangan karena auditor yang memiliki sikap skeptisisme akan selalu mempertanyakan dan mengevaluasi bukti audit secara kritis, serta selalu mencari dan berusaha menemukan informasi baru, semakin banyak informasi yang diperoleh oleh auditor maka akan semakin mampu auditor tersebut membuktikan benar atau tidaknya gejala-gejala kecurangan yang terjadi. Mengingat bahwa skeptisime berpengaruh terhadap pendeteksian kecurangan, maka auditor diharapkan dapat memiliki sikap skeptisisme yang tinggi dalam melakukan proses auditing. Dengan memiliki sikap skeptisisme yang tinggi, auditor diharapkan mampu meningkatkan pencarian akan informasi yang dibutuhkan apabila belum terungkap, pemahaman terhadap perilaku orang lain terutama penyedia informasi, percaya diri dengan kemahiran profesional yang dimiliki, pertimbangan penjelasan dan tanggapan dari orang lain, penekanan pada suatu hal yang dianggap tidak konsisten serta tidak mudah terpengaruh oleh orang lain dan menyimpulkan secara objektif dalam membuktikan gejala-gejala kecurangan yang mungkin terjadi.

Selanjutnya, hasil analisis data menunjukkan bahwa independensi memiliki koefisien positif namun dengan nilai signifikansi yang tidak signifikan. Hasil tersebut menunjukkan bahwa H3 tidak terbukti secara signifikan, yang berarti tingkat independensi auditor tidak berpengaruh secara signfikan terhadap kemampuan pendeteksian kecurangan auditor. Temuan tersebut mendukung penelitian Prasetyo et al. (2019) dan Sulistyowati dan Supriyati (2015), namun di sisi lain hasil penelitian tersebut tidak konsisten dengan penelitian Indrawati et al. (2019), Sofie dan Nugroho (2018), serta Biksa dan Wiratmaja (2016) yang membuktikan bahwa independensi berpengaruh positif terhadap kemampuan mendeteksi kecurangan. Tidak signifikannya pengaruh yang ditimbulkan oleh independensi terhadap pendeteksian kecurangan dapat disebabkan oleh kesulitan untuk mengukur independensi secara akurat dimana keterikatan auditor dan klien bisa jadi ditimbulkan oleh pertemanan atau kekerabatan jauh yang sulit untuk dideteksi. Auditor yang kurang independen juga harus mengikuti prosedur dan 
aturan yang diterapkan oleh standar audit dan KAP yang menaunginya, sehingga ketika prosedur audit dilakukan dengan semestinya, kecurangan klien tetap dapat terdeteksi. Selain itu, ketika auditor memiliki independensi yang tinggi namun tidak dilengkapi dengan kompetensi yang memadai untuk mendeteksi kecurangan maka tidak akan berdampak secara signifikan, dikarenakan untuk dapat mengungkapkan kecurangan klien merupakan hal yang sulit yang membutuhkan kompetensi yang memadai.

Hasil analisis data terkait hipotesis terakhir menunjukkan bahwa koefisien interaksi variabel FRA*EXP memiliki koefisien negatif dan tidak signifikan (sig > $0,05)$ sehingga $\mathrm{H} 4$ dalam penelitian ini ditolak. Hal tersebut menunjukkan bahwa pengalaman tidak dapat memoderasi pengaruh penilaian risiko kecurangan terhadap pendeteksian kecurangan secara signifikan. Hasil tersebut tidak konsisten dengan penelitian Kiswanto dan Maulana (2019) yang menunjukkan bahwa pengalaman dapat memoderasi pengaruh penilaian risiko kecurangan terhadap kemampuan auditor dalam mendeteksi kecurangan. Ketidakmampuan pengalaman dalam memoderasi pengaruh penilaian risiko kecurangan terhadap pendeteksian kecurangan terjadi dikarenakan variasi tingkat pengalaman yang menjadi sampel penelitian ini didominasi dengan tingkat pengalaman yang rendah yaitu sebesar 65,4\% dengan rentang pengalaman 1-5 tahun, sehingga tidak mampu memoderasi pengaruh penilaian risiko terhadap pendeteksian kecurangan. Tidak berbedanya pengaruh penilaian risiko kecurangan terhadap kemampuan pendeteksian kecurangan antara auditor yang berpengalaman dan kurang berpengalaman juga dapat disebabkan oleh adanya kemungkinan auditor yang memiliki penugasan audit yang lebih banyak namun tidak pernah menghadapi klien yang melakukan kecurangan, atau auditor selalu dihadapkan oleh kondisi klien yang serupa sehingga pengalaman penanganan kecurangan klien tidak berbeda dengan auditor yang memiliki masa kerja atau penyelesaian tugas audit yang lebih sedikit.

Mengingat bahwa pengalaman tidak dapat memoderasi pengaruh penilaian risiko kecurangan terhadap kemampuan pendeteksian kecurangan, maka kantor akuntan publik perlu mengadakan pelatihan bagi auditornya dan melakukan pengembangan jabatan terhadap auditor. Hal ini bertujuan agar auditor semakin berpengalaman dan terasah kemampuan menilai risiko kecurangannya dalam mendeteksi tindak kecurangan.

\section{SIMPULAN}

Hasil penelitian menunjukkan bahwa penilaian risiko kecurangan dan skeptisisme merupakan faktor yang signifikan mempengaruhi kemampuan pendeteksian kecurangan auditor secara signifikan. Temuan tersebut memberikan implikasi bagi para auditor khususnya auditor independen untuk berkomitmen melaksanakan dan meningkatkan aktivitas penilaian risiko kecurangan dalam kegiatan audit guna meningkatkan pendeteksian kecurangan yang dilakukan klien. Selain itu, sikap skesptisisme juga harus selalu dijaga oleh seorang auditor dikarenakan sikap tidak mudah percaya tersebut merupakan sikap yang sangat dibutuhkan dalam pendeteksian kecurangan. Penelitian ini gagal membuktikan 
pengaruh independensi terhadap pendeteksian kecurangan serta pengaruh moderasi dari variabel pengalaman terhadap hubungan antara penilaian risiko kecurangan dan pendeteksian kecurangan.

Penelitian ini masih memiliki keterbatasan yang harus diperbaiki yaitu keterbatasan variabel penelitian yang hanya meliputi tiga variabel independen (penilaian risiko kecurangan, skeptisisme dan independensi) dan variabel pengalaman sebagai variabel moderasi. Terdapat banyak faktor lain selain variabel dalam penelitian ini yang diduga dapat mempengaruhi pendeteksian kecurangan, sehingga bagi penelitian selanjutnya dapat mencoba untuk menambahkan variabel lain yang diteliti sehingga hasil penelitian lebih akurat dan komprehensif. Penelitian ini juga hanya menggunakan sampel auditor eksternal yang berada di dua belas Kantor Akuntan Publik (KAP) di wilayah Jakarta Selatan saja sehingga kemampuan generalisasi hasil penelitian masih terbatas. Dan keterbatasan terakhir adalah penelitian ini hanya menggunakan kuesioner untuk pengumpulan data sehingga respon atau informasi yang diperoleh dari auditor sangat terbatas.

Berdasarkan keterbatasan penelitian tersebut, maka saran untuk penelitian selanjutnya yaitu: penelitian selanjutnya diharapkan dapat menggunakan atau menambah selain variabel penilaian risiko kecurangan, skeptisisme, independensi dan pengalaman, memperluas wilayah sampel penelitian yang digunakan sehingga memperkuat generalisasi hasil penelitian, serta menggunakan teknik pengambilan data selain kuesioner seperti melakukan wawancara, eksperimen atau grup diskusi sehingga data yang dikumpulkan dapat lebih akurat dan komprehensif.

\section{DAFTAR PUSTAKA}

Aminudin, Mohamad Rizal dan Dhini Suryandari. (2016). Factors affecting auditor's ability in detecting fraud through professional scepticism. Accounting Analysis Journal, Vol 4, 344-351.

Association of Certified Fraud Examiners Indonesia. (2017). Survei Fraud Indonesia 2016. Jakarta: Association of Certified Fraud Examiners Indonesia Chapter

Association of Certified Fraud Examinary. (2018). Report to the nations 2018, Asia Pacific Edition. Tersedia di https://www.acfe.com

Biksa, Ida Ayu Indira dan I Dewa Nyoman Wiratmaja. (2016). Pengaruh pengalaman, independensi, skeptisme profesional auditor pada pendeteksian kecurangan. E-Jurnal Akuntansi Universitas Udayana, 17(3), 2384-2415.

Butar, Sarina Gabryela A. B. Dan Halim Dedy Perdana. (2017). Penerapan skeptisisme profesional auditor internal pemerintah dalam mendeteksi kecurangan. Jurnal Ekonomi dan Bisnis, 20(1), 169-187.

Dewi, Dewa Ayu Candra dan I Ketut Budiartha. (2015). Pengaruh kompetensi dan independensi auditor pada kualitas audit dimoderasi oleh tekanan klien. EJurnal Akuntansi Universitas Udayana, 11(1), 197-210.

Hurtt, R. K. (2010). Development of a Scale to Measure Professional Skepticism. Auditing: A Journal of Practice \& Theory, 29(1), 149-171.

Institut Akuntan Publik Indonesia. (2018). Standar Profesional Akuntan Publik. Jakarta: Institut Akuntan Publik Indonesia. 
Indrawati, Linda, Dwi Cahyono dan Astrid Maharani. (2019). Pengaruh skeptisisme profesional, independensi auditor dan pelatihan audit kecurangan terhadap kemampuan auditor dalam mendeteksi kecurangan. International Journal of Social Science and Business, Vol 3 (4), 393-402.

Irawan, Kristian Fernando, Rispantyo, dan Dewi Saptantinah Puji Astuti. (2018). Analisis pengaruh pengalaman audit, beban kerja, skeptisme profesional, dan independensi terhadap kemampuan auditor mendeteksi fraud. Jurnal Akuntansi dan Sistem Teknologi Informasi, 14(1), 146-160.

Jaffar, Nahariah, Hasnah Haron, Takiah Mohd Iskandar dan Arfah Salleh. Fraud risk assessment and detection of fraud: the moderating effect of personality. International Journal of Business and Management, Vol 6 (7), 40-50.

Karyono. (2013). Forensic Fraud. Yogyakarta: ANDI

Kiswanto dan Panji Aziz Maulana. (2019). Pengalaman memoderasi penilaian risiko kecurangan, skeptisisme, beban kerja pada kemampuan mendeteksi kecurangan. Jurnal Ilmiah Akuntansi dan Bisnis, 14(2), 183-195.

Koroy, Tri Ramaraya. (2008). Pendeteksian kecurangan (fraud) laporan keuangan oleh auditor eksternal. Jurnal Akuntansi dan Keuangan, 10(1), 22-33.

Mulyadi. (2014). Auditing Buku 1. Jakarta: Salemba Empat

Ningtyas, Indri, Harun Delamat dan Emylia Yuniartie. (2018). Pengaruh pengalaman, keahlian dan skeptisme profesional terhadap pendeteksian kecurangan (Studi empiris pada BPK RI perwakilan Sumatera Selatan. Akuntabilitas: Jurnal Penelitan dan Pengembangan Akuntansi, Vol 12 (2), 113-124.

Putra, Gede Sanjaya Adi dan Anak Agung Ngurah Bagus Dwirandra. (2019). The effect of auitor experience, type of personality and fraud auditing training on auditor's ability in fraud detecting with professional scepticsm as a mediation variable. International Research Journal of Management, IT \& Social Sciences, Vol 6 (2), 31-43.

Prasetyo, Maulana Aji, Edi Sukarmanto dan Mey Maemunah. (2019). Pengaruh skeptisme profesional dan independensi terhadap pendeteksian kecurangan. Kajian Akuntansi, Vol 20 (2), 159-167.

Sari, Kadek Gita Arwinda, Made Gede Wirakusuma, dan Ni Made Dwi Ratnadi. (2018). Pengaruh skeptisisme profesional, etika, tipe kepribadian, kompensasi, dan pengalaman pada pendeteksian kecurangan. E-Jurnal Ekonomi dan Bisnis Universitas Udayana, 7(1), 29-56.

Sastiana dan Sumarlin. (2016). Pengaruh audit forensik dan profesionalisme auditor terhadap pencegahan fraud dengan kecerdasan spiritual sebagai variabel moderating pada perwakilan BPKP provinsi sulawesi selatan. Akuntansi Peradaban, 1(1), 106-127.

Sayed Hussin, S. A. H., Iskandar, T. M., Saleh, N. M., Jaffar, R. (2017). Professional Skepticism and Auditors' Assessment of Misstatement Risks: The Moderating Effect of Experience and Time Budget Pressure. Economics and Sociology, 10(4), 225-250.

Sofie dan Nanda Afriandi Nugroho. (2018). Pengaruh skeptisme profesional, independensi, dan tekanan waktu terhadap kemampuan auditor mendeteksi kecurangan. Jurnal Akuntansi Trisakti, 5(1), 65-80. 
Sulistyowati, Lingga dan Supriyati. (2015). The effect of experience, competence, independence and professionalism of auditors on fraud detection. The Indonesian Accounting Review, Vol 5 (1), 95-110.

Yuara, Safriani. Ridwan Ibrahim, dan Yossi Diantimala. (2018). Pengaruh Sikap Skeptisme Profesional Auditor, Kompetensi Bukti Audit, dan Tekanan Waktu terhadap Pendeteksian Kecurangan Pada Inspektorat Kabupaten Bener Meriah. Jurnal Perspektif Ekonomi Darussalam, 4(1), 69-81. 
EQUITY, Vol. 23, No.1, 2020, 1-18

Halaman ini sengaja dikosongkan

untuk kepentingan penggenapan halaman 